\title{
sciendo
}

Research Article

(C) 2019 Ewa Jurczyk-Romanowska and Piotr Kwiatkowski. This is an open access article licensed under the Creative Commons Attribution-NonCommercial-NoDerivs License (http://creativecommons.org/licenses/by-nc-nd/3.0/).

\section{From Presumption to DNA - Evolution of the Institution of the Parentage of a Child in the One-hundred-year History of Polish Law}

\author{
Ewa Jurczyk-Romanowska, Ph.D. \\ Insitute of Pedagogy, University of Wroclaw \\ Dawida 1, 50-527 Wrocław, Poland \\ Piotr Kwiatkowski, Ph.D. \\ Institute of Pedagogy, University of Wroclaw \\ Dawida 1, 50-527 Wrocław, Poland
}

Doi: $10.2478 / m j s s-2019-0021$

\section{Abstract}

\begin{abstract}
After the end of World War I, in 1918, Poland regained its independence to once again find its place on the map of the world after 123 years. Thus, Polish jurists were faced with the task of creating an entirely new legal order, in the realm of the law of the state system as well as criminal, administrative, civil, and family law. The evolution of the questions pertaining to the parentage of a child was key in the realisation of the child's right to know their identity, in granting children citizenship of the newly founded state of Poland, and in securing their social, civil, and political rights. The laws of the previous governments would clearly stigmatise children born illegitimi thori. The year 1946 brought the first mitigation of the division into marital and non-marital children, and in 1950 the division was abolished. The subsequent legislative changes were aimed to follow the advances in biological and medical sciences. In its directives the Supreme Court wold accept the successive methods of establishing parentage moving gradually from the prevalence of personal sources in court proceedings to that of DNA tests. Exegesis of legal text and analysis of judicial decisions and literature. After one hundred years of adapting legal regulations to social changes and scientific discovery Poland still faces the necessity to regulate the crucial issues of in vitro fertilisation and surrogacy. The one-hundred-years evolution of legislation and jurisdiction in Poland in the context of the development of new methods of establishing parentage is described in the present paper.
\end{abstract}

Keywords: parentage of the child, DNA, jurisdiction, social changes

Mater semper certa est,

pater est quem nuptiae demonstrant

\section{Introduction}

The history of child's rights is not long. The case of Mary Ellen McCormack (Markel, 2009), in which the American Society for the Prevention of Cruelty to Animals had to intervene, caused an outrage among the public in the United States, making the society realise the lack of legal instruments protecting the rights of children. In December 1874 the New York Society for the Prevention of Cruelty to Children was established, and it was recognised as the first association protecting the rights of the youngest members of society in the world. In other countries associations aiming to reduce the criminal liability of underage persons and to establish special educational institutions were founded, and in 1892 the Association for Childhood Education International (ACEI, 2017) was 
organised. However, it was only in the $20^{\text {th }}$ century that child's rights were defined. In 1924 the concise Geneva Declaration of the Rights of the Child (LON, 24) was singed, and in the Universal Declaration of Human Rights (UDHR) from 1948 the United Nations declared that children had the rights to special care and protection (UNGA, 1948). Similarly in the UN Declaration of the Rights of the Child from 1959 it was decided that "with its birth the child has the right to a surname and a citizenship" (UNGA, 1959).Poland was the initiator of the works on the Convention on the rights of the child, started in 1978, which was accepted by the UN in 1989 (Czyż, 2002; UNGA, 1989). The Convention prohibited the discrimination of children for any reason, including birth. In art. 7 it was stated that "a child from the moment of its birth shall have the right to receive a name, a citizenship, and, if possible, the right to now its parents and to remain under their care" (UNGA, 1989, art. 7), while rendering the party states responsible for initiating actions aimed to protect the rights of children to retain their identity, including citizenship, surname, and family relations (UNGA, 1989, art. 8). Therefore, the right to know one's parentage became one of the fundamental rights of the child.

Parentage can be defined in the legal context, when legal regulations, especially those of family law, regulate the problems of the establishment of paternity and maternity, and in the biological context ${ }^{1}$.

When the notion of the protection of child's rights was born, Poland did not exist as a state, and the territories of the former state of Poland were part of Russia, Austria, and Prussia (the so-called "Partitions of Poland"). These states would introduce a number of repercussions after the failed January Uprising (with its outbreak on January 22, 1863). Intensive efforts were made to rid the Polish nation of its language and traditions. In the Vistula Land, also named the Kingdom of Poland, the administrative institutions of Polish character were successively dissolved: the State Council of the Kingdom of Poland, the Commission of Religious Denominations and Public Enlightenment, the Administrative Council (1867), the Commission of Internal Affairs (1868), and the Commission of Revenue and Treasury (1869). As a result, in 1869 the economic autonomy of the Kingdom of Poland was abrogated, and in 1874 the position of the governor-general who would hold the entirety of civil and military power was introduced (Arnold et al., 1990, p. 307). Poland existed only in the minds of the society fighting for their national identity through the voice of its thinkers, writers, and scientists. No Polish law existed at that time, and all the civil issues were decided according to the Russian, Prussian, or Austrian regulations. This was the state of affairs inherited by the creators of the independent Polish state which was established in 1918 after World War I. The creation of a coherent legal order became one of the burning issues. In 1919 the Codification Commission of the Second Republic of Poland was organised. Its aim was to unify legislation, the civil and the criminal law (Act on the codification commission, 1919, art. 2). In 1921 the first constitution was enacted, and therein the parentage of a child was mentioned twice. First of all, the rule was accepted that Polish citizenship was acquired by birth from parents both holding the Polish citizenship (CRP, 1921, art. 88). Thus, the right of blood was instituted. The constitution guaranteed "a complete protection of the life, freedom, and possessions for all regardless of their ancestry, language, race, or religion" (CRP, 1921, art. 94). The term "ancestry" is to be understood in the context of the person's family and social group. The state was obliged to provide care for the children requiring it (CRP, 1921, art. 103). Therefore, the questions of citizenship and the responsibility for the child were linked with establishment of parentage. However, these issues were not regulated in the interwar period. The broadening of the pertaining regulations was to come with the enactment of separate bills, and theretofore the laws from the times of the partitions were in force.

\section{1919-1946. Child from a Marriage or an Orphan}

After the regaining of independence by Poland the questions of family law were not unified by the Polish legislation, which is why the regulations of the legal acts of the previous governments - first

\footnotetext{
${ }^{1}$ In the paper emphasis is placed on the questions connected with the establishment of a child's parentage. Issues connected with adoption and institutional care are not discussed, because they are too broad to be addressed in this article.
} 
of all the Civil code of the Kingdom of Poland, the Austrian civil code, and vol. 10 pt. 1 of the Collection of laws ${ }^{2}-$ remained in force. Working on the assumption that the maternity of a child is always certain, the regulations introduced numerous limitations in the area of the establishment of paternity. The notion of a child from marriage was clearly defined, because the assumption was made that if a child was born during marriage it was the child of the mother's husband and it was kin to both the families of the mother and the father. In the case of children born outside legal marriage it was assumed that they did not have parents in the legal terms. The mother was only the guardian of the child, and in extreme cases (regulations of the Austrian civil code of 1811 Allgemeines Bürgerliches Gesetzbuch) the mother had to be granted the guardianship by a court of law (Fiedorczyk, 2014, p. 126). The law did not provide an opportunity to establish the paternity of children born outside marriage. The institution of equalling the rights of children born in and outside marriage was applied scarcely and was considered an act of grace on behalf of the state (Fiedorczyk, 2014, p. 126). According to statistical data the ratio of childbirth outside marriage was $6 \%$ and such children would typically be born to women not older than 24 (Szukalski, 2001, p. 8). It was customary that "corrective marriages" were entered into by pregnant women with men who may not have been the biological fathers. The laws of the previous governments did not allow mothers to take legal action to deny the recognition of paternity, even when child's rights were being breached (Fiedorczyk, 2014, p. 125).

While the Codification Commission organised in 1919 began to work on family and guardianship laws, the efforts ceased with the outbreak of World War II, and the diverse laws of the previous governments would remain in force until the end of the war. Only after 1945 were the works of the Commission finalised with the issuing of four decrees: Marriage law (1945), Family law (1946), Guardianship law (1946), and Marriage property law (1946). From this moment on the problems of establishing and functioning of families were formally and legally regulated.

\section{1946-1978. The Genesis of the Methods of Establishing Paternity}

\subsection{Family law of 1946.}

In the Family law passed in 1946 the division into marital and non-marital children is sanctioned, which resulted in the differentiation of the duties of biological parents in relation to their children, however, in the context of the laws of the previous governments these regulations ought to be considered progressive because they mitigated the differences, even though children born illegitimi thori would still be socially stigmatised.

\footnotetext{
${ }^{2}$ During the partitions of Poland and in the first years of the existence of the Second Republic of Poland the legal acts of the previous governments, which also regulated family law, remained in force. They included: the criminal code of emperor Joseph II of 1786, called the Joseph Code, the Napoleonic Code of 1907, the Austrian Allgemeines Bürgerliches Gesetzbuch (ABGB) of 1811, the civil code of the Kingdom of Poland of 1825, the German civil code Bürgerliches Gesetzbuch (BGB) of 1900, as well as the Collection of laws of the Russian Empire (Свод законов Российской империи) of 1835. The jurisdiction pluralism on Polish lands led to numerous difficulties with defining the legal status of the citizens of the new Polish state. The regulations were abolished with the decrees introducing a new codification of family law in the broad sense in Poland: Cf. the decree of September 25, 1945 Regulations introducing the marriage law, Journal of laws 1945 Issue 48 pos. 271; the decree of January 22, 1946 Regulations introducing the family law, Journal of laws 1946 Issue 6 pos. 53; the decree of May 14, 1946 Regulations introducing the guardianship law, Journal of laws 1946 Issue 20 pos. 136; the decree of May 29, 1946 Regulations introducing the marriage property law, Journal of laws 1946 Issue 31 pos. 197. The listed decrees include a detailed enumeration of the legal acts or their parts which were repealed as a result of family law reform of 1945-1946. The decree of January 22, 1946 Regulations introducing the family law was crucial for the discussed subject matter because therein 27 legal acts regulating family life were abolished, including those pertaining to establishment of parentage and the status of children born in and out of wedlock - in the territories previously belonging to Austria there were 16 such legal acts (the oldest from 1791), in those belonging to Prussia 3 legal acts (the oldest from 1877), in the territories which had belonged to Russia 2 legal acts (the oldest from 1835), and in the lands of the dependent Kingdom of Poland 5 legal acts (the oldest from 1807), as well as 2 legal acts from the interwar period. What is interesting is that a number of regulations of the Napoleonic Code of 1807 remained in force.
} 
In the case of marital children clear rules of establishing paternity were introduced, and they are still in force today, with certain amendments. A child was presumed to have been born within marriage if its birth occurred during marriage or within 300 days of its dissolution (FL, 1946, art. 5). On this basis it was presumed that the mother's husband was the father and thus the child is marital and it is granted certain rights. The child could bear the father's surname, and both the parents were obliged to provide guardianship, care, and to raise the child. "Presumption of birth within marriage" was altered to "presumption of paternity" ( $F C, 1950$, art. $42 \S 1)$, while the essence of the presumption remained unchanged.

Presumption of birth within marriage could be refuted through legal action to "deny the birth of child within marriage" (FL, 1946, art. 6) which the father could initiate within three months of receiving information about the birth. Depending on the time since entering into marriage the husband of the mother could refute the presumption in two ways. The regular denial consisted in submitting a statement that one is not the father, without the necessity to present any justifying circumstances. Such a statement, placing the burden of proof with the defendant, was sufficient to deny birth of child within marriage if it was not proven probable, in the form of contrary evidence, that the father had had sexual intercourse with the mother of the child between 300 and 180 days before its birth. However, if the child was born after 180 days since the beginning of the marriage the denial of the presumption had to be justified by demonstrating obvious improbability that the husband is the child's father ( $F L, 1946$, art. 6 - confirmed denial). At the same time, the Decree of 1946 denied the mother's husband the right to refute the presumption of birth within marriage if the husband knew about the pregnancy at the time of entering into marriage or had by any means recognised the child, unless such act was the result of deceit (FL, 1946, art. 7). This regulation of the question of parentage was grounded in the social situation. The differentiation between marital and non-marital children implied the social stigmatisation of the latter. That is why it was not uncommon that women in early pregnancy quickly entered into marriages so that their children could enjoy the marital status, the right to bear the mother's husband's surname, and so that the duty to bring up and to provide for the child would lie with both the parents.

In the references it is stated that in Poland in the years after the war 1.8 million non-marital children were born (Szukalski, 2001, p. 3), and the ratio of birth outside marriage in 1948 was estimated to be $8 \%$, dropping to $4 \%$ in the 1960 s. The legal duty to register marriages was introduced in 1945 (Act on acts of marital status, 1945). One of the reasons for the decrease of the ratio was the legalisation of abortion in 1956 (Act on the conditions of permissibility of abortion, 1956). "The Polish society would remain true to the traditional rules calling for "corrective" marriages to remove the odium of "illegitimacy" from the child" (Szukalski, 2001, p. 14).

In the case of non-marital children the Family law decree introduced the new institution of "searching for paternity", as part of which both the mother and child could demand the establishment of paternity through legal action, and the action could be initiated against the father or his inheritors ( $F L, 1946$, art. 46), while one who had had sexual intercourse with the mother between 300 and 180 days before the birth of the child was presumed to be the father ( $F L, 1946$, art. 47). This legal construction of the presumption of paternity has remained in the subsequent codes: Family code of 1950 and Family and guardianship code of 1964. Presumption of paternity could be denied by demonstrating as evidence facts which could raise considerable doubts as to the paternity of the defendant ( $F L, 1946$, art. 47). A situation in which the mother had sexual intercourse with a man other than the defendant presented no obstacle in establishing paternity, and the decision as to whether the defendant can indeed be presumed the father was made by the court on the basis of the evidence presented in the proceedings ( $F L, 1946$, art. 48). If the child was born within the period in which birth within marriage can be presumed the described legal action for paternity could only be initiated if the child was considered non-marital by court (FL, 1946, art. 49). The right to initiate legal action for paternity was also granted to social services if the child remained under the care of a public law institution, unless such action had been previously initiated by the mother or a legal representative (FL, 1946, art. 50).

In the case when a man was established as the father (even when the child was born dead $F L, 1946$, art. 55), he was required to cover the costs of childbirth and a three-month (or longer in specific cases) maintenance of the mother ( $F L, 1946$, art. 54). The court could also grant the 
mother a refund of the costs of other expenses connected with pregnancy and childbirth ( $F L, 1946$, art. 54). If the man had previously promised the mother marriage the court could grant the woman an additional sum for moral damages ( $F L, 1946$, art. 54). This was the case when the promised marriage was not subsequently entered into. Although the establishment of paternity of non-marital children did not lead to relations of kin between the father and his family ( $F L, 1946$, art. 51 a contrario) the decree of 1946 placed the duty to provide for the child on both the parents ( $F L, 1946$, art. 56), and if one of the parents failed to meet the requirements the other parent had to fulfil them while at the same time being granted the right of recourse claim ( $F L, 1946$, art. 58). An interesting solution was the introduction of the responsibility for the costs of raising a non-marital child placed on the inheritors of a deceased father ( $F L, 1946$, art. 60). In spite of these regulations imposing upbringing duties on the father, Family law clearly indicated that the mother was the guardian of a non-marital child (FL, 1946, art. 62).

In the area of parentage and the division of children into marital and non-marital in Family law the legislator introduced three institutions aimed to equalise their legal status. The first of them was "entitlement": a child born before the parents got married was recognised as marital $(F L, 1946$, art. $63)$.

The institution of "recognition" of a child by the father rendered the child marital, and the decree of 1946 did not make it obligatory for the parents to enter into marriage. It was only necessary for the father to recognise the child through "a statement given in front of a guardianship authority, a registry official, a notary, or in a last will" (FL, 1946, art. 64). A action to "deny the recognition of legal force" could be instituted by the mother or the child exclusively and only when the person recognising the child was not indeed the father ( $F L, 1946$, art. 66).

The institution of the "equalisation" of a non-marital child unrecognised by the father with a marital child could be employed when "the parents remained in a de facto marital community or treated the child as if it were a marital child" ( $F L, 1946$, art. 69). The equalisation took place with the decision of a guardianship authority, accepted by a court of appeals, after an application submitted by a mother or a child ( $F L, 1946$, art. 69 and 70). The guardianship authority had the right to deny the equalisation for important reasons, especially if such an act could lead to public outrage ( $F L$, 1946, art. 72).

The construction of the institution of parentage of 1946 was based on pre-war projects (see: Radwański, 2008) which were to a large extent inadequate after the social changes taking place in Poland after World War II. The legalised stigmatisation of non-marital children, the failure to grant the right to enter legal action to deny paternity of the father to married women, the establishment of relations of kin of non-marital children with the mother and her family exclusively, and reducing the role of the father of a non-marital child to providing financial security, as well as the construction of regular denial of birth within marriage with the burden of proof placed on the mother were the expression of a decisive lack of equality between the rights of the parents. Because of the aforementioned inadequacy of the legal regulations of social life works were initiated on a new legal act, which was to regulate the entirety on the problems of family law in Poland.

\subsection{Family code of 1950.}

In July 1948 the newly founded Polish-Czechoslovakian Commission for Legal Cooperation (Szer, 1964; Jurczyk-Romanowska, 2014) initiated its works. In 1949 the commission presented two very similar projects: the Czechoslovakian act on family law and the Polish Family code, which was enacted in 1950 with minor amendments (Ignatowicz, 2000, p. 24; FL, 1950). The distinction between marital and non-marital children was removed. It was undoubtedly connected with the works on a new constitution of Poland which, with its enactment in 1952, made all children legally equal. Article 67 of the Constitution stated that: (1) Marriage and family remain under the protection of the People's Republic of Poland. Numerous families are placed under particular care. (2) Birth outside marriage does not reduce the rights of a child (CPRP, 1952).

The Family code which had gone into effect two years before the new constitution changed the perspective on non-marital children, formalising the relations of kin with the father as well as the mother while at the same time obliging both the parents to be the guardians of the child and its 
possessions, to care for its physical and spiritual development, to provide for the child, and to educate it in a way as to be able to work for the good of the society, with regard to its talents (FC, 1950 , art. 35). Both the parents were obliged to provide for and bring up the child. According to the code, these duties could be fulfilled in part or in entirety by personally caring for the child (FC, 1950, art. 39). While removing the duality of the legal status of children the Family code stated that a child ought to bear the surname of the father. Only in the case when the father was unknown could the child have the mother's surname (FC, 1950, art. 36). This regulation was aimed to reduce the stigmatisation of children born outside marriage.

In relation to establishing paternity the notions of "presumption of birth of the child within marriage" was substituted with "presumption of paternity" in Family code, however, the construction of the institution remained unchanged (FC, 1950, art. $42 \S 1$ ). So was the case with collisions of presumptions: "If a child was born, in fact, within 300 days from the dissolution or annulment of a marriage, but after the mother entering into a new marriage, the second husband is presumed to be the father" ( $F C, 1950$, art. $42 \S 2)$. The legislator specified the statement that "doubts arise as to which marriage the child is from" ( $F L, 1946$, art. $15 \S 2)$ pointing to the duration of 300 days since the dissolution of the first relationship (FC, 1950, art. $42 \S 1$ ).

The husband of the child had the right to enter legal action to deny paternity within 6 months since learning of the birth of the child ( $F C, 1950$, art. 48 - thus, the time to initiate the action was doubled), and the right to enter the action was granted a legal representative of the mother's husband in case of his total incapacitation (FC, 1950, art. 48). However, in contrast to Family law of 1946, the inheritors of the mother's husband were denied the right. This suit was entered against the mother and the child (FC, 1950, art. 50). Two types of denial were maintained: regular denial (if the child was born until 180 days since contracting the marriage), and denial with the necessity to prove the improbability of paternity (if the child was born between 180 and 300 days from the dissolution of marriage). A subtle change to the construction of regular denial was introduced. Family code stated that "to abolish the presumption of paternity it is sufficient for the husband to submit in his action to deny paternity a statement that he is not the father of the child, unless he had had sexual intercourse with the mother of the child between $300^{\text {th }}$ and $180^{\text {th }}$ day before it was born or that when entering into marriage he was aware of the pregnancy" (FC, 1950, art. $49 \S 2)$. Thus, the fact of having had sexual intercourse with the mother within the duration defined in the legal act and awareness of the pregnancy were to make it impossible to employ regular denial of parenthood and to necessitate the entering of the denial with the proof of the improbability of paternity. Thus, the burden of proof lay with the father. Freeing the mother from the duty to make plausible the circumstances of sexual intercourse with the father within the defined duration of time was undoubtedly an improvement of the situation of women in family law, however, what was of even greater importance in the matter was article 51, in which for the first time the mother was granted the right to enter legal action to deny the paternity of her husband within 6 months of childbirth (FC, 1950, art. 51). Before the amendment married women did not have that right, even when the husband was not the biological father. Regardless of the subject initiating the suit, denial of paternity was impossible after the death of the child (FC, 1950, art. 52).

The Family code of 1950 stated that the legal relationship between the father and the child could be established in three ways only: as a result of the aforementioned presumption, through recognition of the child by the father, or through establishment of paternity by a court of law. This regulation organised the dispersed system of presumptions, the circumstances necessary to be proven, and the available institutions of "entitlement", "recognition", and "equalisation" present in the earlier acts. After the enactment of the Family code in 1950 a man could employ the institution of "recognising the child" in front of a registry official or a guardianship authority, but such act required now the mother's agreement, unless she was deceased, was incapacitated, or acquiring her agreement would encounter obstacles difficult to overcome. However, in the latter situation the mother had the right to - when the obstacle was removed and within 6 months of learning of the recognition of the child - to request the annulment of the recognition if the man was not the biological father of the child ( $F C, 1950$, art. 44). It ought to be noted that in the previous regulation the mother did not enjoy this right, and the recognition of the child was a unilateral act of will, which could even be included in one's last will ( $F L, 1946$, art. $64 \S 2$ ). Thus, as a result of the enactment 
of new legal regulations mothers received considerably greater prerogatives connected with the formal paternity of their children. In the new regulations the institution of the recognition of a child was broadened to include the nasciritus, i.e., a yet unborn child $(F C, 1950$, art. 45), which also led to reduced stigmatisation of non-marital children. The new act also granted the father the right to abolish the recognition of a child because of a fault in a statement of will (which was a broader term than the previously employed deceit), but only in the case when he was not indeed the father. The father had six months after the recognition to enter the action (FC, 1950, art. 46).

The right to enter the demand for a court of law to establish paternity belonged to the mother and the child. In this situation it was presumed that the father of the child is the man who had sexual intercourse with the mother between the $300^{\text {th }}$ and the $180^{\text {th }}$ day before birth $(F C, 1950$, art. 47). Thus, the presumption construct form 1946 was retained.

The greatest achievement of the new act was making marital and non-marital children legally equal by introducing common regulations pertaining to parental guardianship and relationships between parents and children. Women were granted more rights connected with presumption of paternity, recognition of a child, and legal establishment of paternity, and the time to employ these institutions was prolonged from 3 to 6 months. This regulation, with a single exception (Decree on the change in the family code, 1953), remained unchanged until 1965 when the Family and guardianship code (FGC, 1964) was enacted, and has been in force until today in its amended form. The exception pertained to granting the child the right to enter legal action to deny being born within marriage, within three years of becoming an adult. The action was initiated against the husband of the mother, and when he was not alive or his place of residence remained unknown, against the curator established by a guardianship authority. Before the child became an adult the mother was its representative in the cases to deny paternity (Decree on the change in the family code, 1953, art. 52).

\subsection{Family and guardianship code of 1964.}

The Family code of 1950 was believed to have been faulty. It regulated all the issues of family law in 93 articles (FC, 1950), whereas the same matter was normalised in decrees in 1945 and 1946 encompassing 245 articles (Marriage law, 1945; FL, 1946; Guardianship law, 1946; Marriage property law, 1946). Despite its conciseness, the Family code constituted a great step forward in providing equal rights of men and women in marriage and family, as well as equal rights for children born within and outside marriage. However, numerous questions remained without legal regulation, which presented courts with substantial difficulties. That is why works on a new legal act were initiated in 1956 in the Codification Commission (Ignatowicz, 2000, pp. 24-25), which resulted in the enactment of Family and guardianship code in 1964. The code went into force on January 1, 1965 (Regulations introducing the Family and guardianship code, 1964), and remains so until today, although it has undergone major amendments in the recent years.

The new legal regulation retained the presumption of paternity in an unchanged form - the mother's husband was still presumed to be the father if the child was born during the marriage or within 300 days of its dissolution. The collision of presumptions was ruled in the same manner when the mother contracted a new marriage within 300 days of the dissolution of the previous one. At the same time it was decided that the presumptions could be abolished only as result of a legal action to deny paternity (FGC, 1964, art. 62), retaining the six-months' time since acquiring the information about childbirth defined in 1950 (FGC, 1964, art. 63). The title to file a lawsuit by a legal representative of the mother's husband was also retained, in the case of him being totally incapacitated because of mental illness or another type of mental disorder, provided he fell ill within the time allowing for the initiation of the legal action (FGC, 1964, art. $64 \S 1$ ). In relation to the previous regulation the catalogue of the reasons was broadened with "other mental disorders", and the opportunity to file a lawsuit by the husband after the incapacitation was abolished, providing additional 6 months after the abolishment, or acquiring the information about childbirth after the abolishment, provided that the legal actions had not been previously entered by a legal representative (FGC, 1964, art. $64 \S 2$ ). A mother's husband afflicted by mental illness or disorder but not incapacitated also received the right to enter a suit according to the same rules as in the 
case of incapacitation (FGC, 1964, art. 65).

As in the regulations of 1946 and 1950 two types of denial of paternity were retained: regular denial and denial with demonstration of improbability that the husband was the father. However, in 1964 we find a clearly expressed relation to the second type of denial - if the husband "had sexual intercourse with the mother of the child no later than in the $300^{\text {th }}$ and no sooner than the $180^{\text {th }}$ day before the birth of the child, or if upon contracting the marriage he was aware of the pregnancy" (FGC, 1964, art. $68 \S 2$ ). The change of the term defining the time of the intercourse ought to be noted. In Family law it was: "in the time from the $300^{\text {th }}$ to the $180^{\text {th }}$ day before the birth of the child" ( $F L, 1946$, art. $6 \S 2)$, and in Family code: "in the time between the $300^{\text {th }}$ and $180^{\text {th }}$ day before its birth" FC, 1950, art. $49 \S 2$ ), and in the Family and guardianship code currently in force there is the definition: "no later than in the $300^{\text {th }}$ and no sooner than the $180^{\text {th }}$ day before the birth of the child" (FGC, 1964, art. 68 § 2). The earlier definitions appear easier to understand, nevertheless, the regulation from 1964 leaves no doubt as to the $180^{\text {th }}$ day - the presumption is not feasible if the intercourse took place on that day. In the earlier regulations this issue was debatable.

In the act of 1964 the previously assumed rights of the mother (6 months since childbirth) (FGC, 1964, art. 69) and the child (three years since becoming an adult) (FGC, 1964, art. 70) to enter a lawsuit to deny paternity were included. In both cases the abolishment of the presumption could only happen as a result of demonstrating the improbability that the mother's husband was the child's father. Each of the subjects in the legal action to deny paternity entered the lawsuit against all the persons whose legal situation could be changed as a result. Thus, they were: the mother's husband against the child and the mother, and, if the mother was deceased, against the child (FGC, 1964, art. 66); the mother against the husband and the child, and, if the father was deceased, against the child (FGC, 1964, art. 69); the child against the husband of its mother and the mother, and, if the mother was deceased, against her husband, while, if the mother's husband was deceased, against a curator assigned by a guardianship court (FGC, 1964, art. 70). Denial of paternity was not allowed after the death of the child (FGC, 1964, art. 71).

In the situation when the aforementioned presumption of paternity did not arise or has been refuted in the course of a legal action to deny paternity, paternity could only be established through recognition or the decision of a court of law (FGC, 1964, art. 72). The child could be recognised by the father. Family and guardianship code broadened the regulations of the previous acts by making the possibility to recognise a child dependant on the capacity to perform acts in law, and the acquiring of required agreements. A man with a full capacity to act in law had the right to recognise a child, when:

- If the child was not an adult - the agreement of the mother was required, and if the mother was deceased, or she had been deprived of parental guardianship, the agreement of a legal representative of the child was required ( $F G C, 1964$, art. $77 \S 1)$,

- If the child was an adult - the agreement of the child and of the mother, and if the mother was deceased or communicating with her encountered obstacles difficult to overcome her agreement was not obligatory (FGC, 1964, art. 77 §3),

- If a yet unborn child (a nasciturus) was to be recognised, the mother's agreement was always required (FGC, 1964, art. $77 \S 2)$,

- If the recognition pertained to a deceased child it was possible only when the child had left descendants (FGC, 1964, art. 76).

A man with limited capacity to act in law had the title to recognise a child when apart from the aforementioned agreements he also received the agreement of his legal representative, however, Family and guardianship code did not define a possibility to recognise the child of a totally legally incapacitated father, even through a legal representative (FGC, 1964, art. 73).

As in the case of previous regulations, the recognition of the child was to take place in front of a registry official or a guardianship court, however, an exception was added: "In the case of a father in immediate danger to life he can recognise the child in front of a member of a local national council or a notary" (FGC, 1964, art. $79 \S 2$ ).

In the act of 1964 the time limit for the abolishment of recognition because of faults in the statement of will was prolonged from 6 months (FC, 1950, art. 46) to one year (FGC, 1964, art. 80), while the title to submit the action was granted to the man who had recognised the child (FGC, 
1964, art. 80) was well as the mother (FGC, 1964, art. $82 \S 2$ ), and the child (FGC, 1964, art. 81). The abolishment of the recognition was to be demanded only when the man who recognised the child was not its father. Also in this case the rule was applied that the legal action was entered against all persons whose legal situation could change (FGC, 1964, art. 82), while employing this institution was not possible after the death of the child (FGC, 1964, art. 83).

The subjects entitled to demand an establishment of paternity by a court of law were the child and the mother, while the latter could only do so before the child became an adult. In the course of a legal establishment of paternity it was presumed that the father of the child was the man who had sexual intercourse with its mother "not later than on the $300^{\text {th }}$ and not sooner than on the $180^{\text {th }}$ day before the birth of the child" (FGC, 1964, art. 85).

Family and guardianship code referred to the regulations of 1946 in stating that "The circumstance in which the mother of the child had at the same time sexual intercourse with another man can be the basis to abolish the presumption only when from the circumstances it can be concluded that the paternity of another man is more probable" (FGC, 1964, art. $85 \S 2$ ). In the regulations of 1946 the court was to decide in the course of the proceedings whether the defendant is the father or not ( $F L, 1946$, art. 48), in Family code of 1950 the issue is not addressed, and in 1964 it was stated that in such situation probability is to be considered.

A legal solution unseen before in Polish family law after the war was granting the prosecutor right of action in all the lawsuits pertaining to parentage in the Family and guardianship law of 1964 (FGC, 1964, art. 86). It ought to me emphasised that the right of action had no time limit, which is why even after the expiration of the time limit for other entitled subjects the legal situation of a child could be changed by a prosecutor - unless the child was dead.

The questions of evidence proceedings were made precise by the jurisdiction. In the sentence of December 18, 1951 the Supreme Court (Sąd Najwyższy; SC) stated that "in those establishment of paternity cases in which the interest of the child, who is under utmost care and protection of the People's State, and in which the interest of the society is present, the court ought take greatest measures to discover the material truth" (DSC, 1951 in: Krzemiński, 1961). Likewise, in 1953 the Supreme Court stated: "The solemnity with which the People's State treats the questions of the family, places the duty to take particular care to discover the material truth on the courts of law in establishment of paternity cases. That is why [...] the court is obliged to make use of the prerogatives defined in art. $236 \S 1$ of the code of civil proceedings, i.e., to routinely accept evidence and conduct investigations aimed to discover it" (Directive of the Supreme Court on the establishment of paternity by courts of law,1952).

In evidence proceedings the method of the analysis of the most probable time of conception in which the dates of sexual intercourse were juxtaposed with the date childbirth was employed. A common argument put forward to support the thesis denying paternity was the fact that the presumed father had no children with women in other relationships (Genetico, n.d.). In 1955 the Supreme Court presumed that when the statements of both the sides are completely consistent, it is not excluded that the evidence proceedings be limited to collecting statements form the sides (DSC, 1951 in: Ignatowicz, 1959, p. 460), therefore, the method could arise naturally, if the statements of the sides were unanimous.

Yet another method employed in the years after the war was anthropological investigation consisting in comparison of quantitative measurements of the human body, conducted with the use of measurement units (the height of the body, weight of the body, length of head) as well as descriptive qualitative features, defined through verbal description (e.g., profile of the nose: straight, concave, bulging) between the investigated persons, e.g., the mother, the child, and the male defendant (Genetico, n.d.). However, this subjective method was not widely recognised and was only employed as supplement. The Supreme Court stated that "evidence from anthropological investigation in establishment of paternity cases cannot, because of its essence, in the current state of science, constitute in and of itself a basis for the establishment or denial of paternity" (Decision of the Voivodship Court for Warsaw, 1958).

In the discussed period the method of establishing paternity which was held in the highest regard was the examination of blood types. The rules of inheritance of the AB0 set were described by Ludwik Hirszfeld - the creator of serological anthropology - in 1924 (Hirszfeld et al., 1924 in: 
Hirszfeld, 1946), which allowed for the inclusion of this test in paternity cases as excluding evidence. In 1948 the Supreme Court noted the indisputability of the method (DSC, 1948), and in 1953 the fact was emphasised in Directives of the Supreme Court in establishing paternity by courts of law, stating that "the rules of inheritance of certain blood types which allow an expert to issue an opinion on the exclusion of paternity have been confirmed empirically, i.e., through observation and experience, on such vast evidence material, that they can be deemed sufficiently reliable [...] That is why if an expert, on the basis of a comparison of blood types, issues an opinion that the paternity of a presumed father is excluded, the result of such evidence ought to be considered as more reliable than evidence from the statements of witnesses and sides of the proceedings, because those are by their nature highly subjective and may turn out to be objectively false" (Directive of the Supreme Court on the establishment of paternity by courts of law, 1952).

The time limit given in establishing paternity was based on two methods of subjective character: witness statements in the analysis of the most probable time of conception and anthropological examination, and one objective method: the blood type test, which provided excluding evidence. Only the development of medicine and genetics provided objective evidence in paternity establishment, while at the same time raising new doubts.

\section{1978-2009. Towards DNA Tests}

In 1976 the Constitution of People's Republic of Poland was amended. The guarantee of equal rights was broadened to state that: "Citizens of the People's Republic of Poland have equal rights regardless of their sex, birth, education, profession, nationality, race, religious denomination, and social position" (Act on the change of the Constitution of the People's Republic of Poland, 1976, pt. 30). It was the first time that the constitution addressed birth and the equality of the rights resulting from it. From the perspective of the discussed subject matter Article 67 of the Constitution was also relevant; therein it was stated that "(2) It is the duty of the parents to raise their children to be honest citizens of the People's Republic of Poland, aware of their rights. (3) People's Republic of Poland secures the realisation of alimony rights and duties. (4) Children born outside marriage have the same rights as children born within marriage" (Act on the change of the Constitution of the People's Republic of Poland, 1976, pt. 38). Thus, the responsibility of both the parents for raising children was directly pointed to and all the differences in the treatment of legitimate and illegitimate children were removed. Such assumption was in accordance with the European Convention on the Legal Status of Children Born out of Wedlock (ECLSCBW) which was signed in Strasbourg on October 15, 1975. Although the Convention was ratified by Poland only in 1996 (Act ratifying the ECLSCBW, 1999), it is doubtless that its directives influenced the amendments to the Constitution of People's Republic of Poland. The Convention stated that the maternity of a non-marital child is decided on the basis of the birth of the child exclusively (COE, 1975, art. 2), which was a reflection of the ancient Roman proverb mater semper certa est. The paternity of a non-marital child, in turn, was to be stated or established in the course of voluntary recognition or the sentence of a court of law (COE, 1975, art. 3). Article 5 of the Convention required that scientific evidence be allowed in court proceedings in paternity cases to establish or exclude paternity (COE, 1975, art. 5). The consequence of the establishment of parentage was the imposing on the parents of non-marital children the same duties as those of the parents of marital children (COE, 1975, art. 6). Non-marital children were also granted inheritance rights (COE, 1975, art. 9).

Meanwhile, no significant changes were introduced to the family law of contemporary Poland until 2009. One of the factors causing the halt in the legislative works was certainly the social and political situation of Poland, which was the first state in the Eastern Bloc to begin political transformation. The end of the 1970s was the time of workers' strikes in Poland, the year 1978 saw Karol Wojtyła, later John Paul II, elected pope, who would call for respect for tradition and dignity. The Independent Self-Governing Labour Union "Solidarność", one of the pillars of anti-communist opposition in the People's Republic of Poland, was started in 1980. On August 14, 1980 the famous protest in Gdańsk shipyards began - it was then that Lech Wałęsa joined in, to become the symbol of the fight for independent Poland, a Peace Nobel Prize winner (1983), and the first freely elected President of Poland. Polish jurists had to yet again face the challenge of creating a new legal order, 
this time based on the rules of the democratic rule of law. In 1997 a new constitution was enacted, termed also the "Human rights constitution", because these were the questions which were regulated in detail in the first part of this legal act. In article 18 of the Constitution it was indicated that "Marriage, as a relationship between a woman and a man, family, maternity, and parentage are protected by the Republic of Poland" and in art. 32 it is broadly guaranteed: "(1) All are equal before law. All have the right to be treated equally by public authorities. (2) No one may be discriminated in political, social, or economic life for any reason whatsoever" (CRP, 1997, art. 32). It is the broadest clause forbidding discrimination in the 100 years of the newest history of Polish law.

The legislator, focusing on the creation of a new political system of the Polish state, has failed to revise family law, however, even though at that time the questions of family law were not the priority, biological and medical sciences were developing dynamically, allowing the introduction of new methods in evidence proceedings. In the 1970s the HLA (Human Leukocyte Antigens) test was included in the methods employed to establish paternity, and the first decision of the Supreme Court in the matter was issued on May 24, 1978 allowing the use of the evidence in judicial practice (DSC, 1978). Because of the high cost of the test and the substantial amount of blood necessary to conduct it the examinations were only carried out as supplement, nevertheless, their number would increase until 1993 (Karpiewska, 2015, p. 193). The beginning of the 1990s made it possible to introduce a new type of evidence to court proceedings in establishment of paternity: the DNA test. One of the first (Berent et al., 2002) Supreme Court decisions on the matter was issued on February 16, 1994 (DSC, 1993). Therein the Court stated that introduction of DNA tests to judicial practice "cannot lead to breaching the rules of the proceedings by limiting the scope of evidence proceedings and the judicial evaluation of evidence". Therefore, originally DNA tests were treated as supplementary, rather than exclusive evidence. The position of the Supreme Court did not change until 1999. In the decision of September 17, 1999 (DSC, 1998) one can read: "As it is commonly known, the circle of the types of evidence serving to deny the presumption of paternity connected with sexual intercourse within the legal time limit of conception has been gradually expanding with the development of natural sciences. To the evidence admissible in Polish judicial practice such as infertility (...), evidence excluding paternity based on the juxtaposition of the time of sexual intercourse between the defendant and the mother of the child with the child's stage of development (...), blood type evidence (...), anthropological examination evidence (...) the DNA test was added at the beginning of the 1990s (...). Contrary to the other types of evidence which can be employed exclusively to exclude the paternity of the defendant with certainty, it makes it possible to confirm that the defendant is the father of the child with probability equalling practical certainty (...)" (DSC, 1998, in: Berent et al., 2002). It may be stated that since that moment DNA tests have been recognised as an objective method allowing to confirm or exclude paternity of the defendant in Polish judicial practice.

\section{After 2009. Mater Semper Cert Est?}

The works on amendments to Family and guardianship code of 1964 resulted in the amendment to the act, passed on November 6, 2008, which was intended to come into force in June 2009. In the area of the presumption of the paternity of the mother's husband the duality of denials was removed. The mother's husband was able to demonstrate that he is not the child's father in each case (FGC, 1964, art. 67) when the child was born within marriage (FGC, 1964, art. 64). The time limit of 6 months since acquiring information about the birth of the child to enter a lawsuit to deny the paternity of the mother's husband was retained, placing social bonds above biological ones. The mother's husband had the right to use the legitimisation of a prosecutor to enter legal action for the denial of paternity after this time, however, the validity of such application remained to be assessed by the prosecutor. As a result, if a child was raised by a married couple, and the husband knew that he is not the father and accepted that fact for more than 6 months, he would lose the legitimacy to deny paternity and to be released of his parental and alimony duties. Similarly in the case of the recognition of a child the legislator provided the man with the time limit of 6 months since the day of acquiring the information that the child was not his to initiate legal action to deny the presumption of paternity. Thus, the legislator deemed the relationship between the parent and 
the child as more important than the biological relationship.

Yet another new solution was the limitation of the right to enter a lawsuit to deny paternity "if the child was conceived as a result of a medical procedure that the father had accepted" (FGC, 1964, art. 68). This regulation was the consequence of the introduction of the in vitro fertilisation into medical practice. The procedure was granted legal status in 2015 (Act on treating infertility, 2015).

In the discussed amendment the rules of establishing maternity were introduced. Art. $61^{9}$ states that "The mother of the child is the woman who has given birth to it" (FGC, 1964, art. $61^{9}$ ), at the same time creating the opportunity to establish and deny maternity, granting the legitimacy in the matter to the mother, the woman entered into the birth certificate, the child, and father, and the man whose paternity has been established in connection with the entering of the personal data of a woman into civil registry documents in the "Mother" section. The regulation is the result of the development of medicine, in vitro fertilisation, as well as surrogacy, the last of which has yet to be regulated by Polish law, which does not distinguish between genetic (the donor of the female gamete), biological (the woman giving birth) (Karpiewska, 2015, p. 190), legal (the woman granted parental power), and social maternity (the woman raising the child).

In the Roman proverb quoted as the motto of the present paper: Mater semper certa est, pater est quem nuptiae demonstrant one can find unshaken certainty as to who the mother of a child is, which has, however, been undermined by achievements in medical sciences. At the same time paternity, which had for thousands of years been connected with being married to the child's mother, has become feasible to determine with certainty. Children born outside marriage, who had for thousands of years been treated as orphans, bastards, and by-blows, stigmatised and cast out into the margins of society, have now been granted equal rights with children born within wedlock, which has become so obvious in the contemporary legal order that detailed regulation is no longer provided. Everything is included in the statement: "All are equal before law" (CRP, 1997, art. 32).

\section{References}

Act on acts of marital status (1945). The decree proclaimed on 25 September, 1945. Journal of Laws 1945.48.272.

Act on the codification commission (1919). Proclaimed on 3 June, 1919. Journal of Laws 1919.44.315.

Act on treating infertility (2015). The act proclaimed on 25 June, 2015. Journal of Laws 2015.1087.

Act on the conditions of the permissibility of abortion (1956). The act proclaimed on 27 April, 1956. Journal of Laws 1956.12.61.

Act on the change of the Constitution of the People's Republic of Poland (1976). The act proclaimed on 10 February, 1976. Journal of Laws 1976.5.29.

Act ratifying the European Convention on the Legal Status of Children Born out of Wedlock (1999). The act proclaimed on 24 April, 1996, ratified 22 September,.1996. Journal of Laws 1999.79.888.

Arnold, S., Kurkiewicz, W., Tatomir, A., and Żurawski, W. (1990). Dzieje Świata: chronologiczny przegląd ważniejszych wydarzeń [History of the world: a chronological review of the most important historical events] (4th ed.). Warszawa: Ludowa Spółdzielnia Wydawnicza.

[ACEI] Association for Childhood Education International (2017). 125 Years and Counting: 1892-2017. [Online] Availiable: https://www.acei.org/about/ (July 10, 2018).

Berent, J., Jacewicz, R., and Szram, P. (2002). Ewolucja poglądów Sądu Najwyższego dotyczących dowodu w badaniach DNA w sprawach dochodzenia ojcostwa [Evolution of the views of the Supreme Court on DNA test evidence in establishment of paternity cases], Archiwum Medycyny Sądowej i Kryminologii, 52. 195204. [Online] Availiable: http://www.amsik.pl/index.php?option=com content\&task=view\&id=184 (July 10, 2018).

[COE] Council of Europe (1975). European Convention on the Legal Status of Children Born out of Wedlock. The act proclaimed on 15 October, 1975. [Online] Availiable: https://rm.coe.int /CoERMPublicCommonSearchServices/DisplayDCTMContent?documentld=0900001680076da4 (July 10, 2018).

[CPRP] Constitution of People's Republic of Poland (1952). The act proclaimed on 22 July, 1952. Journal of Laws 1952.33.232.

[CRP] Constitution of Republic of Poland (1921). The act proclaimed on 3 March, 1921. Journal of Laws 1921.44.267. 
[CRP] Konstytucja Rzeczypospolitej Polskiej (1997). The act proclaimed on 2 April, 1997. Journal of Laws 1997.78.483.

Czyż, E. (2002). Prawa dziecka [Child’s rights]. Warszawa: Helsińska Fundacja Praw Człowieka.

Decree on the change in the family code (1953). The decree proclaimed on 3 June, 1953. Journal of Laws 1953.31.124.

Directive of the Supreme Court on the establishment of paternity by courts of law (1952). C Prez. 166/52 - OSN $31 / 53$.

[DSC] Decision of the Supreme Court (1948). Decision issued 6 July, 1948. C 393/48. Państwo $i$ Prawo, 11/49, 149.

[DSC] Decision of the Supreme Court (1951). Decision issued 18 December, 1951. C 1556/51 - NP 8-9/52 p. 96 and NP $12 / 52$ p. 53.

[DSC] Decision of the Supreme Court (1955). Decision issued 1 October, 1955, in the case 3 CR 782/55.

Decision of the Voivodship Court for Warsaw (1958). Decision issued 23 July, 1958. Cr 923/58 - OSPiKA 80/59.

[DSC] Decision of the Supreme Court (1978). Decision issued 24 May, 1978 in the case II CRN 80/78.

[DSC] Decision of the Supreme Court (1993). Decision issued 16 February, 1994 in the case II CRN 176/93.

[DSC] Decision of the Supreme Court (1998). Decision issued 19 September, 1999 in the case I CKN 1138/98.

[FGC] Family and guardianship code (1964). The act proclaimed on 25 February, 1964. Journal of Laws 1964.9.59.

[FC] Family code (1950). The act proclaimed on 27 June, 1950. Journal of Laws 1950.34.308.

[FL] Family law (1946). The decree proclaimed on 22 January, 1946. Journal of Laws 1946.6.52.

Fiedorczyk, P. (2014). Status prawny dzieci pozamałżeńskiech $w$ prawie rodzinnym pierwszych lat Polski Ludowej [Legal status of non-marital children in the family law of the first years of the People's Republic of Poland]. Miscellanea Historoco-luridica vol. XIII(2). DOI: 10.15290/mhi.2014.13.02.07. 123-138.

Foreign Policy Global Thinkers (2016). [Online] Availiable: https://gt.foreignpolicy.com/2016/category/thechallengers (July 12, 2018).

Genetico (n.d.). Historia ustalania ojcostwa [History of the establishment of paternity]. [Online] Availiable: https://www.genetico.pl/historia_badan.html (July 10, 2018).

Guardianship law (1946). The decree proclaimed on 14 May, 1946. Journal of Laws 1946.20.135.

Hirszfeld, L. (1946). Historia jednego życia [The Story of One Life]. Warszawa: Spółdzielnia Wydawnicza "Czytelnik".

Hirszfeld H., Hirszfeld L., and Brokman H. (1924). On the Susceptibility to Diphteria (Schick Test Positive) with Reference to Inheritance of Blood Groups. Journal of Immunology, 9. 571-591.

Ignatowicz, J. (1959). Kodeks rodzinny [Family Code]. Warszawa: Państwowe Wydawnictwo Naukowe.

Ignatowicz, J. (2000). Prawo rodzinne [Family Law]. Warszawa: Państwowe Wydawnictwo Naukowe.

Jurczyk-Romanowska E. (2014). The Results of the Work of the Polish-Czechoslovakian Legal Cooperation Commission Pertaining to the Legal Situation of Children - the Polish Perspective. Czech-Polish Historical and Pedagogical Journal, 6(1), 77-88.

Karpiewska A. (2015). The Development of Serological and Molecular Methods of Paternity Testing in Poland. Problems of Forensic Sciences, 103, 178-194.

Krzemiński, Z. (1961). Sądowe ustalenie ojcostwa: stan prawny na dzień 1. IX. 1961. [Judicial establishment of paternity: legal status as of September 1, 1961]. Palestra, 5(11), 1-42.

Kuźnicka, D. (2016). Prawo do tożsamości jako prawo dziecka - wybrane zagadnienia [Right to an identity as a child's right - selected issues]. Folia luridica Universitetis Wratislaviensis, 5(2), 181-198.

[LON] League of Nations (1924). Declaration of the Rights of the Child. Adopted 26 September, 1924. [Online] Availiable: http://www.un-documents.net/gdrc1924.htm (July 10, 2018).

Markel, H. (2009, December 14). Case Shined First Light on Abuse of Childen. The New York Times. [Online] Availiable: https://www.nytimes.com/2009/12/15/health/15abus.html?ref=science (July 10, 2018).

Marriage law (1945). The decree proclaimed on 25 September, 1945. Journal of Laws 1945.48.270.

Marriage property law (1946). The decree proclaimed of 29 May, 1946. Journal of Laws 1946.31.196.

Radwański, Z. (2008). Miejsce prawa rodzinnego $w$ systemie prawa [The place of family law in the legal system]. Państwo i Prawo, 1(3), 3-15.

Regulations introducing the family law (1946). The decree proclaimed on 22 January, 1946. Journal of Laws 1946.6.53.

Regulations introducing the Family and guardianship code (1964). The act proclaimed on 25 February, 1964. Journal of Laws 1964.9.60.

Regulations introducing the guardianship law (1946). The decree proclaimed on 14 May, 1946. Journal of Laws 1946.20.136.

Regulations introducing the marriage law (1945). The decree proclaimed on 25 September, 1945, Journal of Laws 1945.48.271.

Regulations introducing the marriage property law (1946). The decree proclaimed on 29 May, 1946. Journal of Laws 1946.31.197. 
Szer, S. (1964). Współpraca polsko-czechosłowacka w zakresie kodyfikacji prawa rodzinnego: próba oceny [Polish-Czechoslovakian cooperation in codification of family law: attempt of an evaluation]. In: W. Osuchowski, M. Sośniak, and B. Walaszek (Eds.), Rozprawy prawnicze: Księga pamiatkowa dla uczczenia pracy naukowej prof. dr. Kazimierza Przybyłowskiego [Legal treatises: A book commemorating the scientific work of prof. Kazimierz Przybyłowski] pp. 355-364. Kraków-Warszawa: Państwowe Wydawnictwo Naukowe.

Szukalski, P. (2001). Płodność i urodzenia pozamałżeńskie w Polsce [Fertility and birth outside marriage in Poland]. Łódź: Wydawnictwo Uniwersytetu Łódzkiego.

[UNGA] United Nations General Assembly (1948). Universal Declaration of Human Rights. Proclaimed by General Assembly Resolution 217(III) on 10 December, 1948. [Online] Availiable: http://www.un.org/en/universal-declaration-human-rights/ (July 10, 2018).

[UNGA] United Nations General Assembly (1959). Declaration of the Rights of the Child. Proclaimed by General Assembly Resolution 1386(XIV) on 20 November, 1959. [Online] Availiable: http://www.undocuments.net/a14r1386.htm (July 10, 2018).

[UNGA] United Nations General Assembly (1989). Convention on the Rights of the Child. Proclaimed by General Assembly Resolution 44/25 on 20 November, 1989. [Online] Availiable: http://www.undocuments.net/crc.htm (July 10, 2018). 